\title{
Estimation of Protein in Jams, Jellies and Juices Available in Bangladesh
}

\author{
Lokonuzzaman Ahmmed, M. Nazrul Islam, M. Saidul Islam, Md. Sher Ali \\ Inorganic Research Laboratory, Department of Chemistry, University of Rajshahi, Rajshahi, Bangladesh
}

Email address:

lokonuzzaman3@gmail.com (L.Zaman)

\section{To cite this article:}

Lokonuzzaman Ahmmed, M. Nazrul Islam, M. Saidul Islam, Md. Sher Ali. Estimation of Protein in Jams, Jellies and Juices Available in Bangladesh. Science Journal of Analytical Chemistry. Vol. 3, No. 4, 2015, pp. 43-46. doi: 10.11648/j.sjac.20150304.12

\begin{abstract}
This paper deals with the study of protein in Jams, Jellies and Juices of different brands available in the market of Bangladesh. Fruits and fruits products are occupying a larger proportion of daily food item of modern civilized nation certainly due to their great food values. Jams, Jellies and Juices also have good food values as these are made from fruit water and sugar. The present study shows that the investigated result of Protein was found in a range of $0.04 \%-0.79 \%$ in jams. The highest protein content $(0.79 \%)$ was found in Best food orange marmalade Jam and the lowest $(0.04 \%)$ was found in Nur Apple Jam. Most of the Jellies contain small amount of protein. Protein was found in a range of $0.02 \%-0.06 \%$ in the present investigated Jellies. Protein is absent in Pran Apple Jelly. Protein content of juices was found in a range of $0.0 \%$ to $0.03 \%$. The highest protein content $(0.03 \%)$ was found in Pran Premium mango Juice and the lowest $(0.01 \%)$ was found in Acme Premium mango Juice and Starship (Mango) Juice. Protein is absent in other four brands. Most of the people like fruits very much but in some cases a few of them don't like that of unknown cause. In that case Jam, Jelly and Juice are only the alternative source of protein in lieu of fruits. In this paper percentage of protein was determined by using biochemical methods.
\end{abstract}

Keywords: Protein, Biochemical Methods, Jams, Jellies and Juices

\section{Introduction}

Every human being requires food for their living as well as for the production of necessary energy like all other animals. Different food contains different proportion of minerals, proteins, carbohydrates and fat. Most of our people are suffering from malnutrition because they are in need of adequate nutritious food. According to the USDA 10 to 35 percent of our calorie intake should come from protein. Every cell in our body contains protein, so meeting our protein requirement is essential for health ${ }^{1-2}$. Proteins are biological polymers composed of amino acids. Amino acids linked together by peptide bonds form a polypeptide chain. One or more polypeptide chains twisted into a 3-D shape form a protein. Proteins have complex shapes that include various folds, loops, and curves. Folding in proteins happens spontaneously. Chemical bonding between portions of the polypeptide is a chain aid in holding the protein together and giving its shape. There are two general classes of protein molecules: globular proteins and fibrous proteins. Globular proteins are generally compact, soluble, and spherical in shape. Fibrous proteins are typically elongated and insoluble. Globular and fibrous proteins may exhibit one or more of four types of structure. These structure types are called primary, secondary, tertiary and quaternary ${ }^{3-8}$. Fruit is occupying a larger proportion of daily food item of modern civilized nation certainly due to their great food values. Jams, Jellies and Juices also have good food values as these are made from fruit, water and sugar. Consumer tests are important to evaluate the development of new products as it is possible to assess the personal response of current or potential customers of a product ${ }^{9}$. Many studies of fruit-based products such as jam have used this type of analysis ${ }^{10-13}$. Jams, Jellies and Juices provide more essential nutrients in significant amounts. Mango juice contain up to $1 \%$ protein. Mango has antioxidant, anticancer and anti-cardiovascular abilities. Because of the high iron content they are suggested for treatment of anemia and are beneficial to women during pregnancy and menstruation. Mangoes contain an enzyme with stomach soothing properties similar to pepsin. This comforting enzyme helps in digestion ${ }^{14}$. In this chapter we determine 
the protein by biochemical methods.

\section{Experimental}

\subsection{Analytical Techniques}

In present investigation, Micro Kjeldahl Method ${ }^{15}$ was used to carry out the protein analysis. A pH meter is utilized to control the $\mathrm{pH}$ level ${ }^{16}$.

\subsection{Reagents and Chemicals}

All chemicals and reagent used were chemicals and reagents grades. All working solutions were also prepared in redistilled water.

\subsection{Estimation of Protein}

\subsubsection{Procedure}

a) Digestion phase

1) About $0.5 \mathrm{~g}$ of sample was taken on a paper sheet.

2. The paper with sample was carefully inserted into the previously cleaned and dried Kjeldahl flask. About $2 \mathrm{~g}$ of catalyst mixture and $10 \mathrm{~mL}$ of conc. $\mathrm{H}_{2} \mathrm{SO}_{4}$ were added into the flask.
3) Then the sample was digested for 2-3 hrs by heating at $350^{\circ} \mathrm{C}-400^{\circ} \mathrm{C}$ in the digestion chamber until the color changes from black to light bottle green.

4) It was then cooled under running tap water.

5) $50 \mathrm{~mL}$ distilled water was added carefully and slowly.

b) Distillation phase

1) $50 \mathrm{~mL}$ boric acid was taken in a $250 \mathrm{~mL}$ conical flask and about 5 drops of mixed indicator solution was added.

2) After cooling the Kjeldahl flask, pinch of pumice stone was taken in the flask to prevent bumping. Then about 33 $\mathrm{mL} 40 \%$ sodium hydroxide was added slowly.

3) Kjeldahl flask was adjusted into the distillation unit.

4) Receiving tube was dipped under 4\% boric acid solution previously taken in a conical flask and distilled for about five hrs.

5. After complete distillation, ammonia absorbed boric acid was taken and titrated against standard $0.1 \mathrm{~N} \mathrm{HCI}$ until the color of the indicator pointed at an acidic condition (from blue to brown color).

\subsubsection{Calculation}

The percentage of protein present in the sample was calculated by the following equation ${ }^{15,17}$

$$
\begin{gathered}
\% \text { of Nitrogen }=\frac{0.014 \times \text { Normality of HCI } \times \text { volume of HCI required } \times 100}{\text { Weight of sample }} \\
\% \text { of Protein }=\% \text { of nitrogen } \times 6.38
\end{gathered}
$$

The percentages of protein in jam, jelly and juice of different brands are given in table-1.2 and 3 respectively.

\section{Results and Discussion}

Table 1, 2 and 3 depict the protein content in Jams, Jellies and Juices of different brands. Among 9 brands of Jams only 3 brands contain small amount of protein. Protein content in jams was found in a range of $0.04 \%-0.79 \%$. The highest protein content $(0.79 \%)$ was found in Best food orange marmalade Jam and the lowest $(0.04 \%)$ was found in Nur Apple Jam. The average values shown and compared in the graph (Fig.1) are of indicative for protein contents in various types of Jams at a glance.

Among 8 brands of Jellies most of them contain small amount of protein. Protein content in Jellies was found in a range of $0.02 \%-0.06 \%$. Protein is absent in Pran Apple Jelly. The average values shown and compared in the graph (Fig.2) are of indicative for protein contents in various types of jellies at a glance.

Protein content of juices was found in a range of $0.0 \%$ to $0.03 \%$. The highest protein content $(0.03 \%)$ was found in Pran Premium mango Juice and the lowest (0.01\%) was found in Acme Premium mango Juice and Starship (Mango) Juice. Protein is absent in other four brands. The average values shown and compared in the graph (Fig.3) are of indicative for protein contents in various types of Juices at a glance.

Protein is indispensable part of the food for animal as it is the chief constituent of the protoplasm which forms the vital part of every living cell. Protein repair body tissue by continuous catabolism in the body and syntheses of new proteins from the amino acids. Plasma protein regulates water balance Protein involved in the regulation of acidbase balance.

Table 1. Protein contents of Jams.

\begin{tabular}{lll}
\hline SL. No & Sample & Protein $(\mathbf{g} \%)$ \\
\hline 1 & Shezan Mango Jam & 0.11 \\
2 & Pran Mango Jam & 0.15 \\
3 & Freshwel Mango Jam & 0.10 \\
4 & Rajshahi Mango Jam & 0.09 \\
5 & Nur Apple Jam & 0.06 \\
6 & Best Food Orange Jam & 0.79 \\
7 & Agro. Pineapple Jam & 0.08 \\
8 & Shezan mixed jam & 0.04 \\
9 & Nur Mixed Jam & 0.05 \\
\hline
\end{tabular}

$\mathrm{g} \%=$ Gram per 100 gram of edible portion

Agro $=$ Agrokomerec 
Table 2. Protein contents of Jellies.

\begin{tabular}{lll}
\hline SL. No & Sample & Protein $(\mathbf{g} \%)$ \\
\hline 1 & Friends Mango Jelly & 0.05 \\
2 & Agrokomerc Mango Jelly & 0.03 \\
3 & Pran Apple Jelly & 0.00 \\
4 & Friends Ornge Jelly & 0.06 \\
5 & BD Orange Jelly & 0.04 \\
6 & Shezan Orange Jelly & 0.02 \\
7 & Pran Orange Jelly & 0.03 \\
8 & Ahmed Guava Jelly & 0.02 \\
\hline
\end{tabular}

$\mathrm{g} \%=$ Gram per 100 gram of edible portion
Table 3. Protein content of Juice in different Brands.

\begin{tabular}{lll}
\hline SL. No & Sample & Protein ( g \% ) \\
\hline 1 & Danish Mango Juice & 0.02 \\
2 & Shezan Juice (Mango) & 0.00 \\
3 & Starship (Mango) & 0.01 \\
4 & ACME Pr. mango Juice & 0.01 \\
5 & Pran Pr.mango Juice & 0.03 \\
6 & Aarong Orange Flavor & 0.00 \\
7 & Aarong Tamarind Juice & 0.00 \\
8 & Frutika Red Grape Juice & 0.00 \\
9 & Pran Jr. Juice (Mango) & 0.02 \\
10 & Pran Fro. Mango Juice & 0.02 \\
\hline
\end{tabular}

$\mathrm{g} \%=$ Gram per 100 edible portion, $\mathrm{Pr}=$ Premium, $\mathrm{Jr}=$ Junior, Fro=Frooto

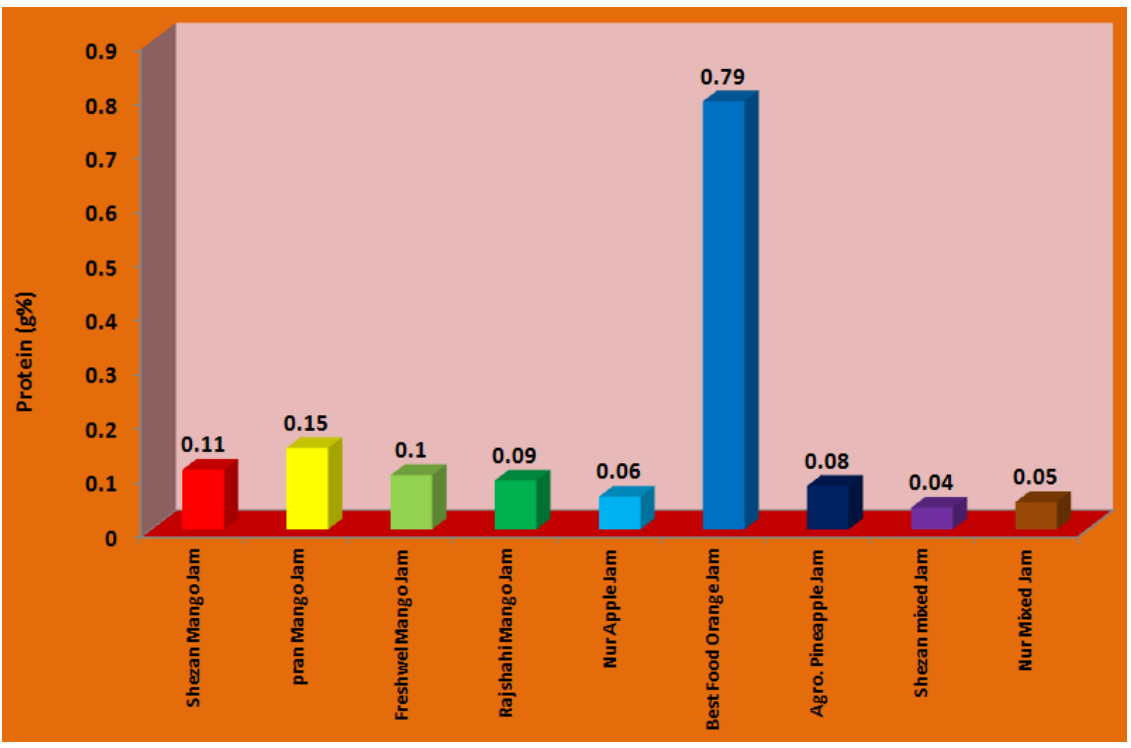

Fig. 1. Comparison of protein status in different jams.

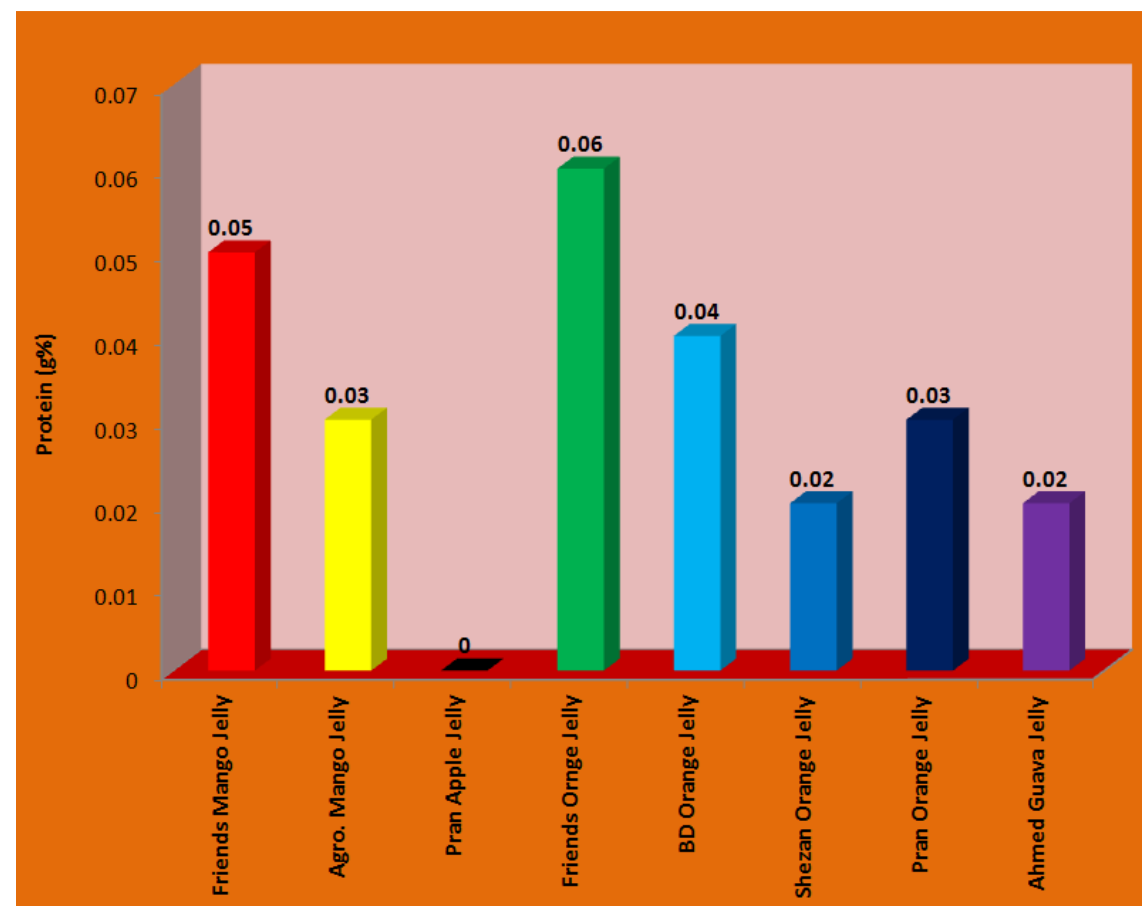

Fig. 2. Comparison of protein status in different jellies. 


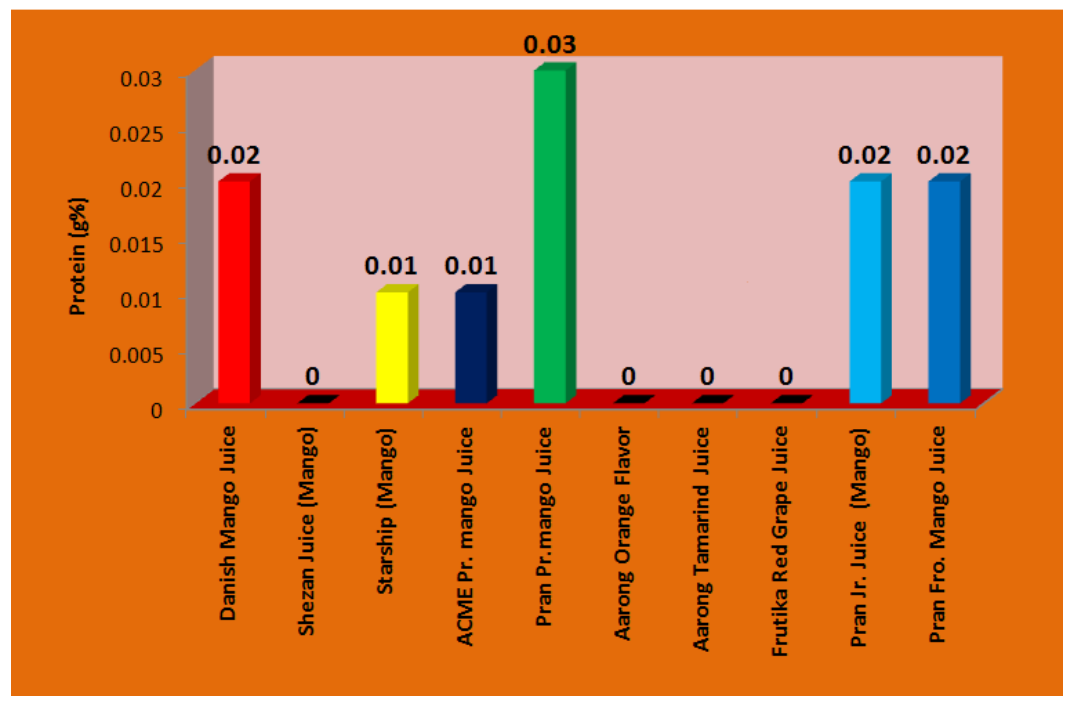

Fig. 3. Comparison of protein status in different juices.

\section{Conclusion}

Fruits of Bangladesh are valuable sources of fiber, some of the essential minerals and vitamins. Around fifty different kinds of fruits are available in Bangladesh. In view of the experimental results of the analysis of different fruit product jams, jellies and juices, it could be concluded that the investigated jams, jellies and juices showed remarkable observations with few exceptions. The information gained from these measurements will provided a baseline level of nutrition for jams, jellies and juices. The data obtained from this study will help to make a food list according to the presence of estimated protein value. This information will also help consumers, manufactures and professionals to realize about the possible sources of the protein in the health care system.

\section{References}

[1] SHEMYAKIN, "Primary Structure Determination of Peptides and Proteins by Mass Spectrometry", Pure appl. Chem., 1968, 17,313 .

[2] HAUROWITZ, The Chemistry and Function of Proteins, Academic Press (1963, 2nd edn)

[3] Fox and Foster, Introduction to Protein Chemistry.

[4] ELMORE, Peptides and Proteins, Cambridge University Press (1968).

[5] BAILEY, Techniques in Protein Chemistry, Elsevier, (1967, 2nd edn.)

[6] Specialist Periodical Reports, The Chemical Society, 'Aminoacid' Peptides and Proteins 'Vol.1 (1969) Vol.2 (1970).

[7] FREEDMAN, "Applications of the Chemical Reactions of Proteins in Studies of their Structure and Function", Quart. Rev., 1971, 25, 431.
[8] BUDZIKIEWICZ, DJERASSI and WILLIAMS, Structure Elucidation of Natural Products by Mass Spectrometry, Holden-Day. Vol. 2 (194). Ch.26." $\alpha$-Amino Acids and Peptides.

[9] Kiin-Kabari DB, Eke-Ejiofor (2013). J. Physico-chemical and sensory properties of cakes and cookies produced from composite flours of wheat and plantain. Wud J Food Technol., 1: 009-013.

[10] Basu S, Shivare US, Singh TV, Beniwal VS (2011). Rheological, textural and spectral characteristics of sorbitol substituted mango jam. J. Food Eng., 105(3): 503-512.

[11] Yuyama LKO, Pantoja L, Maeda RN, Aguiar JP, Silva SB (2008). Development and acceptability of a low calorie cubiu (Solanum sessiliflorum Dunal) jam. Cienc Tecnol Aliment. 28(4): 929-934

[12] Besbes S, Drira L, Blecker C, Deroanne C, Attia H (2009). Adding value to hard date (Phoenix dactylifera L.): Compositional, functional and sensory characteristics of date jam. Food Chem. 112: 406-411. Bligh EG. Dyer WJ (1959). A rapid method of total lipid extraction and purification. Can $\mathrm{J}$ Biochem., 31: 911-917.

[13] Bolini HMA, Alves LR, Battochio JR, Cardoso JMP, Melo LLMM, Silva VS, Siqueira ACP (2008). Time intensity profile and internal preference mapping of strawberry.

[14] Usman, Sabiha Rashid, M.K. Saeed, Imran-ul- Haq PAK. J. FOOD SCI., 2011, 21(1-4), 67-71 Evaluation of quality of mango (Mangifera indica L.) squashes available in Lahore market.

[15] Crampton, E. E.; Harris, L .E. Applied Animal Nutrition, $2^{\text {nd }}$ Ed.; Freeman and Co.: San Francisco, 1969, p 50-53.

[16] W.Horwitz, Official Methods of Analyses, AOAC International, 2002.

[17] James, C. S., Analytical chemistry of food. Seale- Heany Faculty of Agriculture, Food and Land use, Department of Agriculture and Food studies, University of Plymouth, UK, 1 (1995) 96 -97. 